\title{
Soil Microbes for Securing the Future of Sustainable Farming
}

\author{
Sanjay Swami*
}

School of Natural Resource Management, College of Post Graduate Studies in Agricultural Sciences, Central Agricultural University, Umiam (Barapani) - 793 103, Meghalaya, India

*Corresponding author

\section{A B S T R A C T}

\section{Keywords}

Soil microbes,

Functions,

Inoculation

techniques,

mechanism of

action, Sustainable

farming

\section{Article Info}

Accepted:

22 March 2020

Available Online:

10 April 2020
Chemo-centric technological advancement during green revolution period boosted the production potential of our nation. However, over a period of time, this production system has started exhibiting its carrying capacity as reflected by production plateau in green revolution belts. In this context, exploiting the agro-ecosystem services of soil microbial communities appears to be a promising effective approach. This paper reviews the research efforts aimed at improving a sustainable and healthy agricultural production through the appropriate management of soil microorganisms. It deals with the potential microorganisms that can be used as biofertilizers viz. Rhizobia, Azotobacters and Azospirillum, Phosphate-Solubilizing Bacteria (PSB), Vesicular Arbuscular Mycorrhiza (VAM) and Plant Growth Promoting Rhizobacteria (PGPR) along with their functions and inoculation techniques; beneficial microbes, mechanism of action and their significance in securing the future of sustainable farming.

\section{Introduction}

Soils contain natural reserves of plant nutrients, but these reserves are largely in unavailable forms to the plants, and only a minor portion is released each year through biological activity or chemical processes. This release is too slow to compensate the removal of nutrients by agricultural production and to meet crop requirements. Therefore, fertilizers are designed to supplement the nutrients already present in the soil. The use of chemical fertilizer, organic fertilizer or biofertilizer has its advantages and disadvantages in the context of nutrient supply, crop growth and environmental quality. The advantages need to be integrated in order to make optimum use of each type of fertilizer and achieve balanced nutrient management for crop growth. 
The idea of biofertilizer ("bio" which means life and fertilizer which means substances used to deliver plant nutrients in usable form) was first initiated in 1834 when a French agricultural chemist named J. B. Boussingault reported soil nitrogen build-up through legume cultivation (Bhattacharyya, 2014). Hellriegel and Wilfarth (1886), and Beijerinck (1888), a Dutch scientist, further established the concept of biological nitrogen fixation. Subsequently, Noble F. and Hiltner L. (who produced the first rhizobium biofertilizer, Nitragin in 1896), and other scientists have made various contributions and discoveries that have led to full biofertilizer commercialization and use in sustainable agriculture (Bhattacharjee and Dey, 2014; Boraste et al., 2009).

Biofertilizers are substances containing live microorganisms, which when applied to plant surfaces, seeds, roots or soil; colonize the rhizosphere or the interior of plants and help to improve soil fertility while also stimulating plant growth by increasing the availability of plant nutrients and growth substances to the host crops (Figueiredo et al., 2011; Suyal et al., 2016; Vessey, 2003). The term biofertilizer is sometimes used interchangeably with "microbial inoculant, bioinoculant, inoculum or bioformulation" (Gupta et al., 2007; Hassen et al., 2016; Suyal et al., 2016) or effective microorganisms (Megali et al., 2015). Biofertilizers comprised of bacteria, blue-green algae (BGA) and fungi (separately or in combination), and can be made in solid, powdered, granular carrier materials or liquids. The carrier materials sustain the microbial inoculants and allow the product to be stored for longer period (Boraste et al., 2009; Rashid et al., 2016). The beneficial microbes may be rhizospheric; colonizing the surface or intercellular spaces of the plant roots, or endophytic; where they colonize the tissue or apoplastic space within the host plants (Gupta et al., 2012; Malusà et al., 2016). Biofertilizers should not be misunderstood for organic fertilizers such as compost, animal manure and plant manure or extracts (Carvajal-Muñoz and CarmonaGarcia, 2012; Malusá et al., 2012; Vessey, 2003). However, whether the beneficial microbes improve crop accessibility to nutrients (Egamberdiyeva, 2007; Mujawar, 2014) or replenish soil nutrients (Shridhar, 2012; Thamer et al., 2011), if the overall nutrient condition of crop and soil has been improved, such substances containing the beneficial microorganisms are considered as biofertilizers (Vessey, 2003).

\section{Rhizosphere of the soil-plant system}

The rhizosphere is the zone of soil surrounding the root which is affected by it. The significance of the rhizosphere arises from the release of organic material from the root and the subsequent effect of increased microbial activity on nutrient cycling and plant growth. In the rhizosphere the quantities and the types of substrates are different from those in the bulk soil and this leads to colonization by different populations of bacteria, fungi, protozoa and nematodes. Other physicochemical factors which can be different in this region are acidity, moisture and nutrient status, electrical conductivity and redox potential. The association between organisms and roots can be beneficial (water uptake, soil stabilization, growth promotion, $\mathrm{N}_{2}$ fixation, biocontrol, antibiosis, symbiosis), harmful (infection, phytoxicity) or neutral (nutrient flux, free enzyme release, attachment, alleopathy, competition) - these effects often depend on soil conditions and therefore must be regarded as variable. Interactions that are beneficial to agriculture include mycorrhizae, legume nodulation and production of antimicrobial compounds that inhibit the growth of pathogens. Clearly the goal in manipulating the rhizosphere must be to increase the balance of beneficial effects as 
the rhizosphere is deeply affected by fertilization.

\section{Microorganisms used as biofertilizers and their functions}

\section{Rhizobia}

Rhizobia are symbiotic bacteria that fix atmospheric $\mathrm{N}_{2}$ gas in plant root nodules and have a mutually helpful relationship with their host plants. The plant roots supply essential minerals and newly synthesized substances to the bacteria. Because of their N-fixing ability, legumes are less reliant on inorganic $\mathrm{N}$ fertilizer than many other non-legume crops such as cereals and pasture grasses. $\mathrm{N}$ fixation by legumes can also maintain soil fertility and can be of benefit to the following crop. Rhizobium inoculation is a well-known agronomic practice to ensure adequate $\mathrm{N}$ supply for legumes in place of $\mathrm{N}$ fertilizer. It is reported that rhizobium can fix $50-300 \mathrm{~kg}$ $\mathrm{N}$ ha ${ }^{-1}$. Heavier application of inocula mixed into peat granules trickled into soil as the seeds are planted is an alternative technique to encourage nodulation.

\section{Azotobacters and Azospirillum}

These are free-living bacteria that fix atmospheric nitrogen in cereal crops without any symbiosis and they do not need a specific host plant. Azotobacters are abundant in well drained, neutral soil. They can fix $15-20 \mathrm{~kg}$ $\mathrm{ha}^{-1} \mathrm{~N}$ per year. Azotobacter sp. can also produce antifungal compounds to fight against many plant pathogens. They also increase germination and vigor in young plants leading to improved crop stands.

\section{Phosphate-solubilizing bacteria (PSB)}

Under acidic or calcareous soil conditions, large amounts of phosphorus are fixed in the soil but are unavailable to the plants.
Phosphobacterins, mainly bacteria and fungi, can make insoluble phosphorus available to the plant. The solubilization effect of phosphobacterins is generally due to the production of organic acids that lower the soil $\mathrm{pH}$ and bring about the dissolution of bound forms of phosphate. It is reported that PSB culture increased yield up to $200-500 \mathrm{~kg} \mathrm{ha}^{-1}$ and thus 30 to $50 \mathrm{~kg}$ of superphosphate can be saved (Fig. 1).

\section{Vesicular arbuscular mycorrhiza (VAM)}

Mycorrhizae are mutually beneficial (symbiotic) relationships between fungi and plant roots. VAM fungi infect and spread inside the root. They possess special structures known as vesicles and arbuscules. The plant roots transmit substances (some supplied by exudation) to the fungi, and the fungi aid in transmitting nutrients and water to the plant roots.

The fungal hyphae may extend the root lengths 100-fold. The hyphae reach into additional and wetter soil areas and help plants absorb many nutrients, particularly the less available mineral nutrients such as phosphorus, zinc, molybdenum and copper. Some VAM fungi form a kind of sheath around the root, sometimes giving it a hairy, cottony appearance. Because they provide a protective cover, mycorrhizae increase seedling tolerance to drought, to high temperatures, to infection by disease fungi and even to extreme soil acidity.

Application of VAM produces better root systems which combat root rotting and soil borne pathogens. The greatest growth response to mycorrhizal fungi is probably in plants in highly weathered tropical acid soils that are low in basic cations and P, and may have toxic levels of aluminium. Plants that have coarse or limited root systems should benefit the most. 


\section{Plant growth promoting rhizobacteria (PGPR)}

PGPR represent a wide variety of soil bacteria which, when grown in association with a host plant, result in stimulation of host growth. PGPR modes include fixing $\mathrm{N}_{2}$, increasing the availability of nutrients in the rhizosphere, positively influencing root growth and morphology and promoting other beneficial plant-microbe symbioses.

Some researchers have indicated that PGPR will often have multiple modes of action. Ratti et al., (2001) found that a combination of the arbuscular mycorrhizal fungi Glomus aggregatum, the PGPR Bacillus polymyxa and Azospirillum brasilense maximized biomass and $\mathrm{P}$ content of the aromatic grass palmarosa (Cymbopogon martinii) when grown with an insoluble inorganic phosphate.

\section{Inoculation of biofertilizers}

Biofertilizers are generally applied to soil, seeds or seedlings, with or without some carrier for the microorganisms, for example, peat, composts or stickers. Regardless of methods, the number of cells reaching the soil from commercial products is smaller than the existing numbers of soil or rhizosphere microorganisms; these added cells are unlikely to have a beneficial impact on the plant unless multiplication occurs. In addition, the population of introduced microorganisms will decline and be eliminated in a very short time, often days or weeks.

The formulation of inocula, method of application and storage of the product are all critical to the success of a biological product. Short shelf life, lack of suitable carrier materials, susceptibility to high temperature, problems in transportation and storage are biofertilizer bottlenecks that still need to be solved in order to obtain effective inoculation.

\section{Seed inoculation}

Seed inoculation uses a specific strain of microbe that can grow in association with plant roots; soil conditions have to be favorable for the inoculants to perform well. Selected strains of N-fixing Rhizobium bacteria have proven to be effective as seed inoculants for legumes. The seed treatment can be done with any of two or more bacteria without antagonistic effect. In the case of seed treatment with Rhizobium, Azotobacter, Azospirillum along with PSB, first the seeds must be coated with Rhizobium or Azotobacter or Azospirillum. When each seed has a layer of the aforesaid bacteria then the PSB inoculant has to be treated on the outer layer of the seeds. This method will provide maximum numbers of population of each bacterium to generate better results.

\section{Soil inoculation}

In soil inoculation, microbes are added directly to the soil where they have to compete with microbes already living in the soil that are already adapted to local conditions and greatly outnumber the inocula. Inoculants of mixed cultures of beneficial microorganisms have considerable potential for controlling the soil microbiological equilibrium and providing a more favorable environment for plant growth and protection. Therefore, adequate quality control and a high level of consistency in performance and benefits must be ensured. Although inoculations with PSBs have not been very effective, joint inoculation of PSBs with mycorrhizae and $\mathrm{N}_{2}$-fixing bacteria have been successful.

\section{Potential significance of beneficial microbes in sustainable agriculture}

The rhizosphere, which is the narrow zone of soil surrounding plant roots, can comprise up 
to $10^{11}$ microbial cells per gram of root (Egamberdieva et al., 2008) and above 30,000 prokaryotic species that in general, improve plant productivity (Mendes et al., 2013). The collective genome of rhizosphere microbial community enveloping plant roots is larger compared to that of plants and is referred as microbiome (Bulgarelli et al., 2013), whose interactions determine crop health in natural agro-ecosystem by providing numerous services to crop plants viz., organic matter decomposition, nutrient acquisition, water absorption, nutrient recycling, weed control and bio-control (Berg et al., 2013). The metagenomic study provides the individual the core rhizosphere and endophytic microbiomes activity in Arabidopsis thaliana using 454 sequencing (Roche) of 16S rRNA gene amplicons (Hirsch and Mauchline, 2012). It has been proposed that exploiting tailor-made core microbiome transfer therapy in agriculture can be a potential approach in managing plant diseases for different crops (Gopal et al., 2013). Rhizosphere microbial communities an alternative for chemical fertilizers has become a subject of great interest in sustainable agriculture and biosafety programme.

A major focus in the coming decades would be on safe and eco-friendly methods by exploiting the beneficial micro-organisms in sustainable crop production (Nina et al., 2014). Such microorganisms, in general, consist of diverse naturally occurring microbes whose inoculation to the soil ecosystem advances soil physicochemical properties, soil microbes biodiversity, soil health, plant growth and development and crop productivity (Sahoo et al., 2013a). The agriculturally useful microbial populations cover plant growth promoting rhizobacteria, $\mathrm{N}_{2}$-fixing cyanobacteria, mycorrhiza, plant disease suppressive beneficial bacteria, stress tolerance endophytes and bio-degrading microbes (Singh et al., 2011). Biofertilizers are a supplementary component to soil and crop management traditions viz., crop rotation, organic adjustments, tillage maintenance, recycling of crop residue, soil fertility renovation and the bio-control of pathogens and insect pests, which operation can significantly be useful in maintaining the sustainability of various crop productions (Sahoo et al., 2013b). Azotobacter, Azospirillum, Rhizobium, cyanobacteria, phosphorus and potassium solubilizing microorganisms and mycorrhizae are some of the PGPRs that were found to increase in the soil under no tillage or minimum tillage treatment (Dogan et al., 2011; Aziz et al., 2012). Efficient strains of Azotobacter, Azospirillum, Phosphobacter and Rhizobacter can provide significant amount of nitrogen to Helianthus annus and to increase the plant height, number of leaves, stem diameter percentage of seed filling and seed dry weight (Dhanasekar and Dhandapani, 2012). Similarly, in rice, addition of Azotobacter, Azospirillum and Rhizobium promotes the physiology and improves the root morphology (Choudhury and Kennedy, 2004). Azotobacter plays an important role in the nitrogen cycle in nature as it possesses a variety of metabolic functions (Sahoo et al., 2013a).

Besides playing role in nitrogen fixation, Azotobacter has the capacity to produce vitamins such as thiamine and riboflavin (Revillas et al., 2000), and plant hormones viz., indole acetic acid (IAA), gibberellins (GA) and cytokinins (CK) (Abd El-Fattah et al., 2013). A. chroococcum improves the plant growth by enhancing seed germination and advancing the root architecture (Gholami et al., 2009) by inhibiting pathogenic microorganisms around the root systems of crop plants (Mali and Bodhankar, 2009). This genus includes diverse species, namely, $A$. chroococcum, A. vinelandii, A. beijerinckii, $A$. nigricans, $A$. armeniacus and $A$. paspali. It is used as a biofertilizer for different crops viz., 
wheat, oat, barley mustard, seasum, rice, linseeds, sunflower, castor, maize, sorghum, cotton, jute, sugar beets, tobacco, tea, coffee, rubber and coconuts (Wani et al., 2013). Azospirillum is another free-living, motile, gram variable and aerobic bacterium that can thrive in flooded conditions (Sahoo et al., 2014) and promotes various aspects of plant growth and development (Bhattacharyya and Jha, 2012). Azospirillum was shown to exert beneficial effects on plant growth and crop yields both in greenhouse and in field trials (Saikia et al., 2013). Diverse species of the genus Azospirillum including A. lipoferum, $A$. brasilense, A. amazonense, A. halopraeferens and $A$. irakense have been reported to improve productivity of various crops (Sahoo et al., 2014).

Interestingly, it was observed that Azospirillum inoculation can change the root morphology via producing plant growth regulating substances (Bashan et al., 2004) via siderophore production (Sahoo et al., 2014). It also increases the number of lateral roots and enhances root hairs formation to provide more root surface area to absorb sufficient nutrients (Mehdipour-Moghaddam et al., 2012). This improves the water status of plant and aids the nutrient profile in the advancement of plant growth and development (Sarig et al., 1992; Ilyas et al., 2012). Co-inoculation of Azospirillium brasilense and Rhizobium meliloti plus 2,4-D posed positive effect on grain yield and $\mathrm{N}, \mathrm{P}$, K content of Triticum aestivum (Askary et al., 2009). Rhizobium has been used as an efficient nitrogen fixer for many years. It plays an important role in increasing yield by converting atmospheric nitrogen into usable forms (Sharma et al., 2011). Being resistant to different temperature ranges, Rhizobium normally enters the root hairs, multiplies there and forms nodules (Nehra et al., 2007). Rhizobium inoculants in different locations and soil types were reported to significantly increase the grain yields of bengal gram (Patil and Medhane, 1974), lentil (Rashid et al., 2012), pea, alfalfa and sugar beet rhizosphere (Ramachandran et al., 2011), berseem (Hussain et al., 2002), ground nut (Sharma et al., 2011) and soybean (Grossman et al., 2011). These Rhizobium isolates obtained from wild rice have been reported to supply nitrogen to the rice plant to promote growth and development (Peng et al., 2008). One of the species of Rhizobium, Sinorhizobium meliloti 1021 infects plants other than leguminous plants like rice to promote growth by enhancing endogenous level of plant hormone and photosynthesis performance to confer plant tolerance to stress (Chi et al., 2010). In groundnut, IRC-6 strain of Rhizobium has resulted in the enhancement of several useful traits such as increased number of pink coloured nodules, nitrate reductase activity and leghaemoglobin content in 50 DAI (days after inoculation) (Sharma et al., 2011). Rhizobial symbiosis provides defense to plants against pathogens and herbivores, such as example, Mexican bean beetle (Thamer et al., 2011) and the green house whitefly Trialeurodes vaporariorum (Menjivar et al., 2012) (Figure 2).

\section{Biofertilizers exploitation and nutrients profile of crops}

A key advantage of beneficial microorganisms is to assimilate phosphorus for their own requirement, which in turn available as its soluble form in sufficient quantities in soil. Pseudomonas, Bacillus, Micrococcus, Flavobacterium, Fusarium, Sclerotium, Aspergillus and Penicillium have been reported to be active in the solubilization process (Pindi and Satyanarayana, 2012). A phosphate-solubilizing bacterial strain NII0909 of Micrococcus sp. has polyvalent properties including phosphate solubilisation and siderophore production (Dastager et al., 2010). Similarly, two fungi Aspergillus 
fumigates and A. Niger were isolated from decaying cassava peels were found to convert cassava wastes by the semi-solid fermentation technique to phosphate biofertilizers (Ogbo, 2010). Burkholderia vietnamiensis, stress tolerant bacteria, produces gluconic and 2ketogluconic acids, which involved in phosphate solubilization (Park et al., 2010). Enterobacter and Burkholderia that were isolated from the rhizosphere of sunflower were found to produce siderophores and indolic compounds (ICs) which can solubilize phosphate (Ambrosini et al., 2012).

Potassium solubilising microorganisms (KSM) such as genus Aspergillus, Bacillus and Clostridium are found to be efficient in potassium solubilisation in the soil and mobilize in different crops (Mohammadi and Yousef, 2012). Mycorrhizal mutualistic symbiosis with plant roots satisfies the plant nutrients demand (Kogel et al., 2006), which leads to enhance plant growth and development, and protect plants from pathogens attack and environmental stress (Lamabam et al., 2011). It leads to the absorption of phosphate by the hyphae from outside to internal cortical mycelia, which finally transfer phosphate to the cortical root cells (Smith et al., 2011). Nitrogen fixing cyanobacteria such as Aulosira, Tolypothrix, Scytonema, Nostoc, Anabaena and Plectonema are commonly used as biofertilizers (Abdel-Lateif et al., 2012; Roy and Srivastava, 2013). Besides the contribution of nitrogen, growth-promoting substances and vitamins liberated by these algae Cylindrospermum musicola increase the root growth and yield of rice plants. Interestingly, genetic engineering was used to improve the nitrogen fixing potential of Anabaena sp. strain PCC7120 (Pandey et al., 2013). Constitutive expression of the hetR gene driven by a light-inducible promoter enhanced HetR protein expression, leading to higher nitrogenase activity in Anabaena sp. strain PCC7120 as compared with the wildtype strain. This in turn caused better growth of paddy when applied to the fields (Chaurasia and Apte, 2011).

\section{Biofertilizers relevance and plant tolerance to environmental stress}

Abiotic and biotic stresses are the major constraints that are affecting the productivity of the crops. Many tools of modern science have been extensively applied for crop improvement under stress, of which PGPRs role as bio protectants has become paramount importance in this regard (Yang et al., 2009). Rhizobium trifolii inoculated with Trifolium alexandrinum showed higher biomass and increased number of nodulation under salinity stress condition (Hussain et al., 2002; Antoun and Prevost, 2005). Pseudomonas aeruginosa has been shown to withstand biotic and abiotic stresses (Pandey et al., 2012). Paul and Nair (2008) found that P. fluorescens MSP-393 produces osmolytes and salt-stress induced proteins that overcome the negative effects of salt. $P$. putida Rs-198 enhanced germination rate and several growth parameters viz., plant height, fresh weight and dry weight of cotton under condition of alkaline and high salt via increasing the rate of uptake of $\mathrm{K}^{+}, \mathrm{Mg}^{2+}$ and $\mathrm{Ca}^{2+}$, and by decreasing the absorption of $\mathrm{Na}^{+}$(Yao et al., 2010). Few strains of Pseudomonas conferred plant tolerance via 2,4-diacetylphloroglucinol (DAPG) (Schnider-Keel et al., 2000).

Systemic response was found to be induced against $P$. syringae in Arabidopsis thaliana by P. fluorescens DAPG (Weller et al., 2012). Calcisol produced by PGPRs viz., $P$. alcaligenes PsA15, Bacillus polymyxa $\mathrm{BcP} 26$ and Mycobacterium phlei MbP18 provides tolerance to high temperatures and salinity stress (Egamberdiyeva, 2007). It has been demonstrated that inoculation of plant with AM fungi also improves plant growth under 
salt stress (Ansari et al., 2013). Achromobacter piechaudii was also shown to increase the biomass of tomato and pepper plants under $172 \mathrm{mM} \mathrm{NaCl}$ and water stress (Alavi et al., 2013). Interestingly, a root endophytic fungus Piriformospora indica was found to defend host plant against salt stress (Ansari et al., 2013). In one of the studies it was found that inoculation of PGPR alone or along with AM like Glomus intraradices or $G$. mosseae resulted in the better nutrient uptake and improvement in normal physiological processes in Lactuca sativa under stress conditions. The same plant treated with $P$. mendocina increased shoot biomass under salt stress (Kohler and Caravaca, 2010). Mechanisms involved in osmotic stress tolerance employing transcriptomic and microscopic strategies revealed a considerable change in the transcriptome of Stenotrophomonas rhizophila DSM14405T in response to salt stress (Gao et al., 2012). Combination of AM fungi and $\mathrm{N}_{2}$-fixing bacteria helped the legume plants in overcoming drought stress (Aliasgharzad et al., 2006). Effect of A.brasilense along with AM can be seen in other crops such as tomato, maize and cassava (German et al., 2000; Casanovas et al., 2002; Creus et al., 2005). A. brasilense and AM combination improved plant tolerance to various abiotic stresses (Joe et al., 2009). The additive effect of Pseudomonas putida or Bacillus megaterium and AM fungi was effective in alleviating drought stress (Marulanda et al., 2009).

Application of Pseudomonades sp. under water stress improved the antioxidant and photosynthetic pigments in basil plants. Interestingly, combination of three bacterial species caused the highest CAT, GPX and APX activity and chlorophyll content in leaves under water stress (Heidari and Golpayegani, 2012). Pseudomonas sp. was found to cause positive effect on the seedling growth and seed germination of A. officinalis L. under water stress (Liddycoat et al., 2009). Photosynthetic efficiency and the antioxidative response of rice plants subjected to drought stress were found to increase after inoculation of arbuscular mycorrhiza (RuizSanchez et al., 2010). The beneficial effects of mycorrhizae have also been reported under both the drought and saline conditions (Aroca et al., 2013). Heavy metals such as cadmium, lead, mercury from hospital and factory waste accumulate in the soil and enter plants through roots (Gill et al., 2012). Azospirillium sp., Phosphobacteria sp. and Glucanacetobacter sp. isolated from rhizosphere of rice field and mangroves were found to be more tolerant to heavy metal specially iron (Gill et al., 2012; Samuel and Muthukkaruppan, 2011). P. potida strain 11 (P.p.11), P. potida strain 4 (P.p.4) and $P$. fluorescens strain 169 (P.f.169) can protect canola and barley plants from the inhibitory effects of cadmium via IAA, siderophore and 1-aminocyclopropane-1-carboxylate deaminase (ACCD) (Baharlouei et al., 2011). It was reported that rhizoremediation of petroleum contaminated soil can be expedited by adding microbes in the form of effective microbial agent (EMA) to the different plant species such as cotton, ryegrass, tall fescue, and alfalfa (Tang et al., 2010). PGPRs as biological agents proved to be one of the alternatives of chemical agents to provide resistance to against various pathogen attacks (Murphy et al., 2000).

Apart from acting as growth-promoting agents they can provide resistance against pathogens by producing metabolites (Backman and Sikora, 2008). Bacillus subtilis GBO3 can induce defense-related pathways viz., salicylic acid (SA) and jasmonic acid (JA) (Ryu et al., 2004). Application of PGPR isolates viz., B. amyloliquefaciens $937 \mathrm{~b}$ and $B$. pumilus SE-34 provide immunity against tomato mottle virus (Murphy et al., 2003). B. 
megaterium IISRBP 17, characterized from stem of black pepper, acts against Phytophthor capsici (Aravind et al., 2009). Bacillus subtilis $\mathrm{N} 11$ along with mature composts was found to control Fusarium infestation on banana roots (Zhang et al., 2011). Similarly, B. subtilis (UFLA285) was found to provide resistance against $R$. solani and also it induced foliar and root growth in cotton plants (Medeiros et al., 2011). In another interesting study, Paenibacillus polymyxa SQR-21 was identified as a potential agent for the bio-control of Fusarium wilt in watermelon (Ling et al., 2011). Further, the exploitation of PGPRs was found to be effective to manage the spotted wilt viruses in tomato (Murphy et al., 2000), cucumber mosaic virus of tomato and pepper (Murphy et al., 2003), and banana bunchy top virus in banana (Harish et al., 2009). In some cases it was shown that along with bacteria, mycorrhizae can also confer resistant against fungal pathogens and inhibit the growth of many root pathogens such as $R$. solani, Pythium sp., F. Oxysporum, A. obscura and H. annosum (Khalil et al., 2002; Riedlinger et al., 2006) by improving plant nutrients profile and thereby productivity (Ansari et al., 2013). For instance Glomus mosseae was effective against Fusarium oxysporum $f$. sp. Basilica which causes root-rot disease of basil plants (Toussaint et al., 2008). Medicago tranculata also showed induction of various defenserelated genes with mycorrhizal colonization (Liu et al., 2007). It was shown that addition of arbuscular mycorrhizal fungi and Pseudomonas fluorescens to the soil can reduce the development of root-rot disease and enhance the yield of Phaseolus vulgaris L. (Neeraj, 2011).

\section{Mechanism of action of various biofertilizers}

Mycorrhiza is the association of fungus with the roots of higher plants. While it remains an enigma, it serves as a model system to understand the mechanism behind stimulation of growth in the root cells as a result of mycorrhizal inhabitation. Genome sequencing of two EM fungi (ectomycorrhizae), the $L$. bicolor 13, and T. melanosporum (black truffle) 14, helps in the identification of factors that regulate the development of mycorrhiza and its function in the plant cell (Bonfante and Genre, 2010). Fifteen genes that up-regulated during symbiosis were identified as putative hexose transporters in $L$. bicolor. Its genome lacked genes encoding invertases making it dependent on plants for glucose. However, melanosporum possesses one invertase gene, and unlike L. bicolor it can directly use the sucrose of the host (Bonfante and Genre, 2010). The upregulation of transporter genes during symbiosis indicated the action of transportation of useful compounds like amino acids, oligopeptides and polyamines through the symbiotic interface from one organism to other. Free living mycelium can take nitrate and ammonium from the soil. Subsequently, these compounds reach the mantle and hartig net and are then transferred to the plants. Cysteine-rich proteins (MISSP7) of fungus play an important role as effectors and facilitators in the formation of symbiotic interfaces (Plett et al., 2011). Many genes related to auxin biosynthesis and root morphogenesis showed up-regulation during mycorrhizal colonization (Ansari et al., 2013; Splivallo et al., 2009; Abdel-Raouf et al., 2012). Further, G. versiforme possesses inorganic phosphate $(\mathrm{Pi})$ transporters on its hyphae which help in the direct absorption of phosphate from the soil and a glutamine synthase gene was found in G. intraradice, which strengthens the possibility of nitrogen metabolism in fungal hyphe that can be transported later to the plant (Salvioli et al., 2012). Bioactive compounds called Myc factors similar to Nod factors of Rhizobium are suggested to be secreted by mycorrhiza 
and Rhizobium and perceived by host roots for the activation of signal transduction pathway or common symbiosis (SYM) pathway (Kosuta, 2003; Roberts et al., 2013).

The pathways that prepare plant for both AM and Rhizobium infection have some common points. The common SYM pathway prepares the host plant to bring about changes at the molecular and anatomical level with the first contact of fungal hyphae. So far, calcium is supposed to be the hub of secondary messengers via $\mathrm{Ca}^{2+}$ spiking in the nuclear region of root hairs (Sieberer et al., 2009). Rhizobium leguminosarum biovar viciae can induce various genes in the plants like pea, alfalfa and sugar beet as evident from the microarray studies (Ramachandran et al., 2011). PGPR produce IAA which, in turn, induces the production of nitric Oxide (NO), which acts as a second messenger to trigger a complex signaling network leading to improved root growth and developmental processes (Molina-Favero et al., 2007). Expression of ENOD11 and many defenserelated genes and root remodelling genes get up-regulated during entry. Subsequently, this allows the formation of a pre-penetration apparatus or PPA (Bucher et al., 2009). Though the biology behind the development of arbuscules is unknown, a gene called vapyrin when knocked down causes a decline in the growth of arbuscules (Bapaume and Reinhardt, 2012). Many other genes including subtilisin protease 65 , phosphate transporter 66 or two $\mathrm{ABC}$ transporters 67 are known to be involved in arbuscules formation (Zhang et al., 2010; Tromas et al., 2012). Nitrogen fixation genes are popularly used by scientists today to create engineered plants that can fix atmospheric nitrogen. The induction of nif genes in case of nitrogen fixing bacteria takes place under low concentration of nitrogen and oxygen in the rhizosphere. Interestingly, sugarcane plantlets inoculated with a wild strain of G. diazotrophicus, have demonstrated fixation of radioactive $\mathrm{N}_{2}$ when compared with the $G$. diazotrophicus mutant that has mutant nif $D$ gene which proved the significance of nif genes. Efficiency of nitrogen fixation is dependent on the utilization of carbon (Sevilla et al., 2001; Bertalan et al., 2009). A bacterium like Bacillus subtilis (UFLA285) can differentially induce 247 genes in cotton plant as compared to control where no PGPR was supplied to the cotton plant (Baharlouei et al., 2011). Many disease resistance genes that work via jasmonate/ethylene were identified which include metallothionein-like protein type 1 , a NOD26-like membrane integral protein, ZmNIP2-1, a thionin family protein, an oryzain gamma chain precursor, stressassociated protein 1 (OsISAP1), probenazoleinducible protein PBZ1 and auxin and ethylene-responsive genes (BrusamarelloSantos et al., 2012). The expression of the defense-related proteins PBZ1 and thionins were found to get repressed in the rice- $\mathrm{H}$ seropedicae association, suggesting the modulation of plant defense responses during colonisation (Brusamarello-Santos et al., 2012). Among the PGPR species, Azospirillum was suggested to secrete gibberellins, ethylene and auxins (Perrig et al., 2007). Some plant associated bacteria can also induce phytohormone synthesis, for example lodgepole pine when inoculated with Paenibacillus polymyxa had elevated levels of IAA in the roots (Bent et al., 2001). Rhizobium and Bacillus were found to synthesize IAA at different cultural conditions such as $\mathrm{pH}$, temperature and in the presence of agro waste as substrate (Sudha et al., 2012). Ethylene, unlike other phytohormones, is responsible for the inhibition of growth of dicot plants (Ansari et al., 2013). It was found by Glick et al., (1998) that PGPR could enhance the growth of plant by suppressing the expression of ethylene. Interestingly, a model was suggested in which it was shown that ethylene synthesis from 1- 
aminocyclopropane-1-carboxylate (ACC), an immediate precursor of ethylene, which is hydrolyzed by bacterial ACC-deaminase enzyme in the need of nitrogen and carbon source is also one of the mechanisms of induction of conditions suitable for growth. ACC-deaminase activity was also found in the bacteria such as Alcaligenes sp., Bacillus pumilus, Pseudomonas sp. and Variovorax paradoxus (Ansari et al., 2013).

Figure.1 Biofertilizer technology employs plant-microbe interactions in influencing plant growth and development

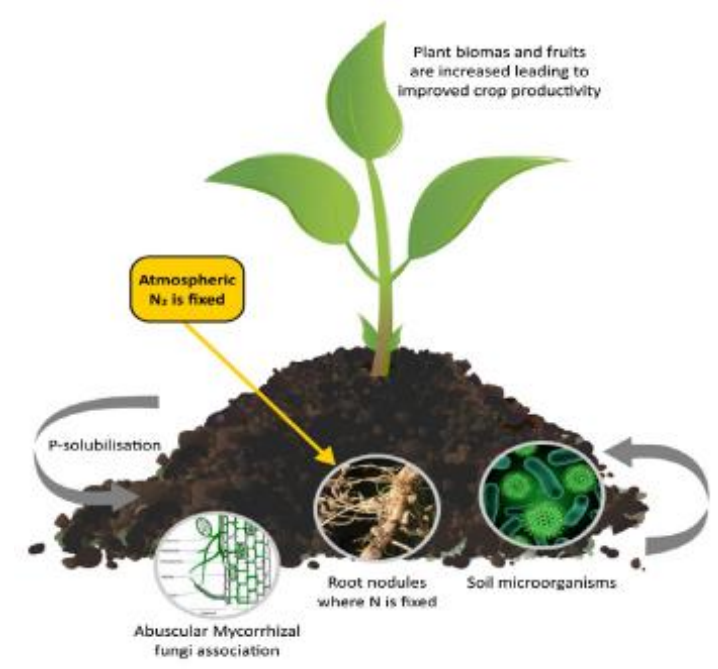

Figure.2 Potential use of soil microbes in sustainable crop production

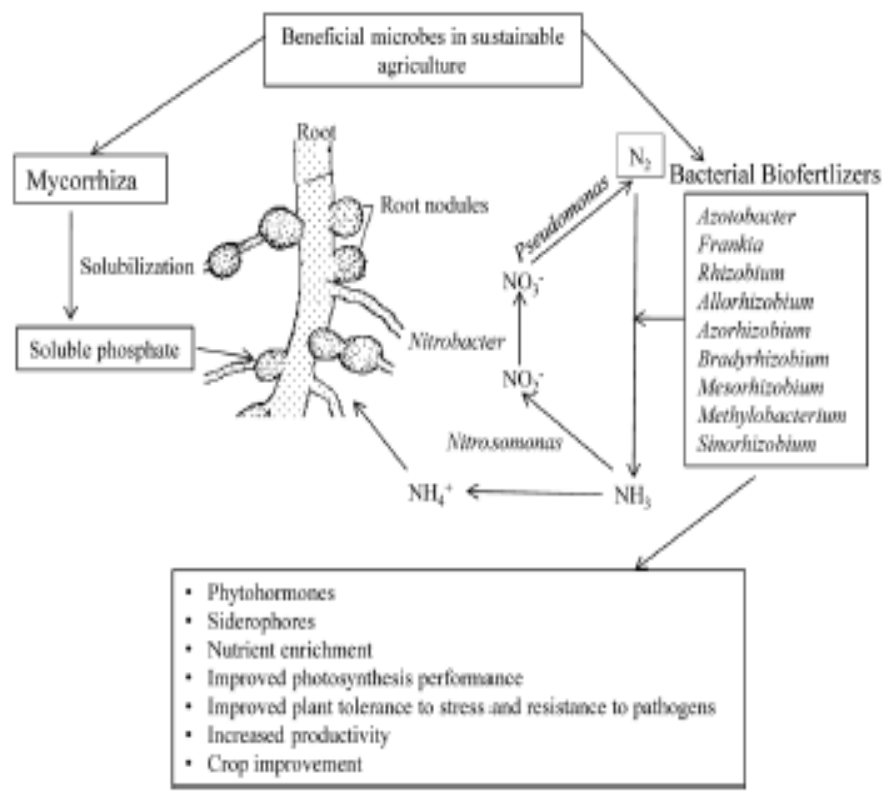


Figure.3 Hypothetical mechanism of action of biofertilizers in the root cell

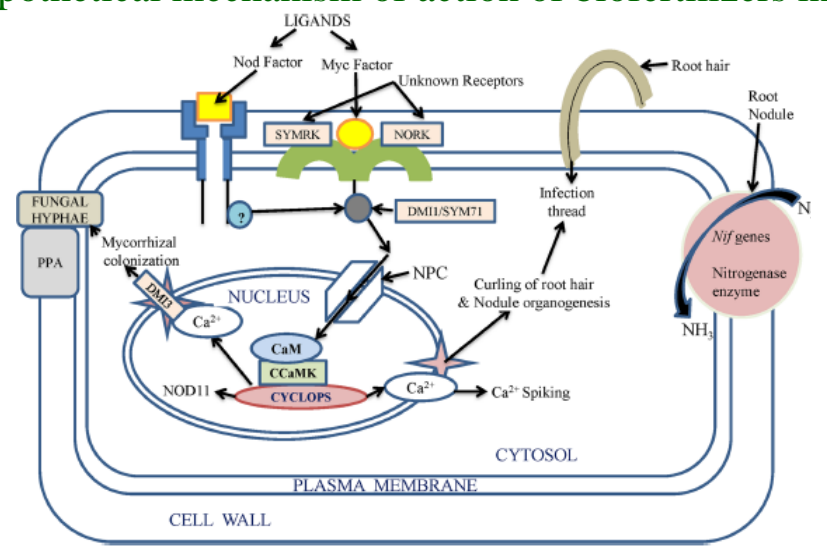

The involvement of ACC deaminase in the indirect influence on the growth of plants was proved in Canola, where mutations in ACC deaminase gene caused the loss of effect of growth promoting Pseudomonas putida (Bhattacharyya and Jha, 2012). The potential of PGPRs was further enhanced by introducing genes involved in the direct oxidation (DO) pathway and mineral phosphate solubilisation (MPS) into some useful strains of PGPRs. Gene encoding glucose dehydrogenase (gcd) involved in the DO pathway was cloned and characterized from Acinetobacter calcoaceticus and E. coli and Enterobacter asburiae (Tripura et al., 2007). Also a soluble form of gcd has been cloned from Acinetobacter calcoaceticus and G. oxydans (Sashidhar and Podile, 2010). Furthermore there are reports of site directed mutagenesis of glucose dehydrogenase $(\mathrm{GDH})$ and gluconate dehydrogenase (GADH) that has improved the activity of this enzyme. Mere substitution of S771M provided thermal stability to $E$. coli while mutation of glutamate 742 to lysine improved the EDTA tolerance of E. coli PQQGDH. The application of this technology was achieved by transferring genes involved in the DO pathway viz., GDH, GADH and pyrroloquinoline quinine (PQQ) to rhizobacteria, and phosphoenolpyruvate carboxylase (PPC) to P. Fluorescens, provide the MPS trait (Sashidhar and Podile, 2010) (Figure 3).

Conclusion of the study are as follows:

In current agriculture practices, chemical fertilizers have reduced the fertility of soil, making it unsuited for raising crop plants. Additionally, the excessive use of these inputs has also led to severe health and environmental hazards such as soil erosion, water contamination, pesticide poisoning, falling ground water table, water logging and depletion of biodiversity. Biofertilizers spontaneously activates the microorganisms found in the soil in an effective and ecofriendly way, thereby gaining more importance for utilization in crop production, restoring the soils fertility and protecting it against drought, soil diseases and thus stimulate plant growth. Biofertilizers lead to soil enrichment and are suitable with longterm sustainability. Further, they pose no danger to the environment and can be substituted with chemical fertilizers. The application of bio-fertilizers can minimize the use of chemical fertilizers, decreasing environmental hazards, enhance soil structure and promote agriculture. Biofertilizers are cheaper and remarkable in affecting the yield of cereal crops. Bio-fertilizers being important components of organic farming 
play a key role in maintaining long term soil fertility and sustainability by fixing insoluble $\mathrm{P}$ in the soil into forms available to plants, thus increasing their effectiveness and availability. In context of both the cost and environmental impact of chemical fertilizers, excessive reliance on the chemical fertilizers is not a useful strategy in the long run due to the cost, both in domestic resources and foreign exchange; participate in setting up of fertilizer plants and maintaining the production. Biofertilizers are the alternative sources to meet the nutrient requirement of crops. In Biofertilizers, beneficial bacteria are Azotobacter, Azospirillium, Rhizobium, Mycorrhizae which are very essential in crop production. Biofertilizer can also make plant resistant to unfavorable environmental stresses.

\section{References}

Abd El-Fattah, D.A., Ewedab, W.E., Zayed, M.S. and Hassaneina, M.K. (2013). Effect of carrier materials, sterilization method, and storage temperature on survival and biological activities of Azotobacter chroococcum inoculants. Ann Agric Sci, 58, 111-118.

Abdel-Lateif, K., Bogusz, D. and Hocher, V. (2012). The role of flavonoids in the establishment of plant roots endosymbioses with arbuscular mycorrhiza fungi, rhizobia and Frankia bacteria. Plant Signal Behav, 7, 636-641.

Abdel-Raouf, N., Al-Homaidan, A.A. and Ibraheem, I.B.M. (2012). Agricultural importance of algae. Afr J Biotechnol, 11, 11648-11658.

Alavi, P., Starcher, M.R., Zachow, C., Müller, H. and Berg, G. (2013). Root-microbe systems: The effect and mode of interaction of stress protecting agent (SPA) Stenotrophomonas rhizophila DSM14405T. Front Plant Sci, 4, 141.

Aliasgharzad, N., Reza, M., Neyshabouri-Salimi, G. (2006). Effects of arbuscular mycorrhizal fungi and Bradyrhizobium japonicum on drought stress of soybean.
Biologia, 19, 324-328.

Ambrosini, A., Beneduzi, A., Stefanski, T., Pinheiro, F., Vargas, L. and Passaglia, L. (2012). Screening of plant growth promoting Rhizobacteria isolated from sunflower Helianthus annuus L. Plant \& Soil, 356, 245-264.

Ansari, M.W., Trivedi, D.K., Sahoo, R.K., Gill, S.S. and Tuteja, N. (2013). A critical review on fungi mediated plant responses with special emphasis to Piriformospora indica on improved production and protection of crops. Plant Physiol Biochem, 70, 403-410.

Antoun, H. and Prevost, D. (2005). Ecology of plant growth promoting rhizobacteria. In: PGPR: Biocontrol and Biofertilization. (Ed.) Siddiqui, Z.A. Dordrecht: Springer, 138.

Aravind, R., Kumar, A., Eapen, S.J. and Ramana, K.V. (2009). Endophytic bacterial flora in root and stem tissues of black pepper (Piper nigrum L.) genotype: Isolation, identification and evaluation against Phytophthora capsici. Lett Appl Microbiol, 48, 58-64.

Aroca, R., Ruiz-Lozano, J.M., Zamarreno, A.M., Paz, J.A., García-Mina, J.M., Pozo, M.J. and Lopez-Raez, J.A. (2013). Arbuscular mycorrhizal symbiosis influences strigolactone production under salinity and alleviates salt stress in lettuce plants. $J$ Plant Physiol, 170, 47-55.

Askary, M., Mostajeran, A., Amooaghaei, R. and Mostajeran, M. (2009). Influence of the coinoculation Azospirillum brasilense and Rhizobium meliloti plus 2,4-D on grain yield and N, P, K content of Triticum aestivum (cv. Baccros and Mahdavi). Am Eurasian J Agric Environ Sci, 5, 296-307.

Aziz, G., Bajsa, N., Haghjou, T., Taule, C., Valverde, A., Mariano, J. and Arias, A. (2012). Abundance, diversity and prospecting of culturable phosphate solubilizing bacteria on soils under croppasture rotations in a no-tillage regime in Uruguay. Appl Soil Ecol, 61, 320-326.

Backman, P.A. and Sikora, R.A. (2008). Endophytes: An emerging tool for biological control. Biol Control, 46, 1-3.

Baharlouei, K., Pazira, E. and Solhi, M. (2011). 
Evaluation of inoculation of plant growthpromoting Rhizobacteria on cadmium. Singapore: International Conference on Environmental Science and Technology IPCBEE Vol.6 IACSIT Press.

Bapaume, L. and Reinhardt, D. (2012). How membranes shape plant symbioses: Signaling and transport in nodulation and arbuscular mycorrhiza. Front Plant Sci, 3, 223.

Bashan, Y., Holguin, G. and Bashan, L.E. (2004). Azospirillum-plant relationships: Agricultural, physiological, molecular and environmental advances (1997-2003). Can J Microbiol, 50, 521-577.

Beijerinck, M. (1888). The root-nodule bacteria. Botanische Zeitung, 46, 725-804.

Bent, E., Tuzun, S., Chanway, C.P. and Enebak, S. (2001). Alterations in plant growth and in root hormone levels of lodgepole pines inoculated with rhizobacteria. Can $J$ Microbiol, 47, 793-800.

Berg, G., Zachow, C., Müller, H., Phillips, J. and Tilcher, R. (2013). Next-generation bioproducts sowing the seeds of success for sustainable agriculture. Agronomy, 3, 648656.

Bertalan, M., Albano, R., de-Pádua, V., Rouws, L., Rojas, C., Hemerly, A., Teixeira, K., Schwab, S., Araujo, J., Oliveira, A., França, L., Magalhães, V., Alquéres, S., Cardoso, A., Almeida, W., Loureiro, M.M., Nogueira, E., Cidade, D., Oliveira, D., Simão, T., Macedo, J., Valadão, A., Dreschse, M., Freitas, F., Vida, M., Guedes, H., Rodrigues, E., Meneses, C., Brioso, P., Pozzer, L., et al., (2009). Complete genome sequence of the sugarcane nitrogen-fixing endophyte

Gluconacetobacter diazotrophicus Pal5. BMC Genomics, 10, 450.

Bhattacharjee, R. and Dey, U. (2014). Biofertilizer, a way towards organic agriculture: A review. African Journal of Microbiology Research, 8(24), 2332-2343.

Bhattacharyya, P. (2014). Biofertilizer use in organic farming: A practical and challenging approach. In: Organic Farming and Sustainability, (eds.) P.K. Shetty, C. Alvares and A.K. Yadav, Banglore: National Institute of Advanced Studies, $\mathrm{p}$.
157.

Bhattacharyya, P.N. and Jha, D.K. (2012). Plant growth-promoting rhizobacteria (PGPR): Emergence in agriculture. World $J$ Microbiol Biotechnol, 28, 1327-1350.

Bonfante, P. and Genre, A. (2010). Mechanisms underlying beneficial plant-fungus interactions in mycorrhizal symbiosis. Nat Commun, 27, 1-48.

Boraste, A., Vamsi, K., Jhadav, A., Khainar, Y., Gupta, N., Trivedi, S. and Mujupara, A. (2009). Biofertilizers: A novel tool for agriculture. International Journal of Microbiology Research, 1(2), 23-31.

Brusamarello-Santos, L., Pacheco, F., Aljanabi, S., Monteiro, R., Cruz, L., Baura, V., Pedrosa, F., Souza, E. and Wassem, R. (2012). Differential gene expression of rice roots inoculated with the diazotroph Herbaspirillum seropedicae. Plant Soil, 356, 113-125.

Bucher, M., Wegmüller, S. and Drissner, D. (2009). Chasing the structures of small molecules in arbuscular mycorrhizal signalling. Curr Opin Plant Biol, 12, 500507.

Bulgarelli, D., Schlaeppi, K., Spaepen, S., Loren, V., van Themaat, E. and Schulze-Lefert, P. (2013). Structure and functions of the bacterial microbiota of plants. Annu Rev Plant Biol, 64, 807-838.

Carvajal-Muñoz, J. and Carmona-Garcia, C. (2012). Benefits and limitations of biofertilization in agricultural practices. Livestock Research for Rural Development, 24(3), 1-8.

Casanovas, E.M., Barassi, C.A. and Sueldo, R.J. (2002). Azospirillum inoculation mitigates water stress effects in maize seedlings. $\mathrm{Cer}$ Res Commun, 30, 343-350.

Chaurasia, A.K. and Apte, S.K. (2011). Improved eco-friendly recombinant Anabaena $s p$. strain PCC7120 with enhanced nitrogen biofertilizer potential. Appl Environ Microbiol, 77, 395-399.

Chi, F., Yang, P., Han, F., Jing, Y. and Shen, S. (2010). Proteomic analysis of rice seedlings infected by Sinorhizobium meliloti 1021. Proteomics, 10, 1861-1874.

Choudhury, M.A. and Kennedy, I.R. (2004). Prospects and potentials for system of 
biological nitrogen fixation in sustainable rice production. Biol Fertil Soils, 39, 219227.

Creus, C.M., Graziano, M., Casanovas, E.M., Pereyra, M.A., Simontacchi, M. and Puntarulo, S. (2005). Nitric oxide is involved in the Azospirillum brasilenseinduced lateral root formation in tomato. Planta, 221, 297-303.

Dastager, S.G., Deepa, C.K. and Pandey, A. (2010). Isolation and characterization of novel plant growth promoting Micrococcus $s p$. NII-0909 and its interaction with cowpea. Plant Physiol Biochem, 48, 987992.

Dhanasekar, R. and Dhandapani, R. (2012). Effect of biofertilizers on the growth of Helianthus annuus. Int J Plant, Ani Environ Sci, 2, 143-147.

Dogan, K., Kamail-Celik, I., Mustafa-Gok, M. and Ali, C. (2011). Effect of different soil tillage methods on rhizobial nodulation, biomass and nitrogen content of second crop soybean. Afr J Microbiol Res, 5, 31863194.

Egamberdieva, D., Kamilova, F., Validov, S., Gafurova, L., Kucharova, Z. and Lugtenberg, B. (2008). High incidence of plant growth stimulating bacteria associated with the rhizosphere of wheat grown on salinated soil in Uzbekistan. Environ Microbiol, 10, 1-9.

Egamberdiyeva, D. (2007). The effect of plant growth promoting bacteria on growth and nutrient uptake of maize in two different soils. Applied Soil Ecology, 36(2-3), 184189.

https://doi.org/10.1016/j.apsoil.2007.02.005

Figueiredo, M.V.B., Seldin, L., de Araujo, F.F. and Mariano, R.L.R. (2011). Plant growth promoting rhizobacteria: Fundamentals and applications. In: Plant Growth and Health Promoting Bacteria, (ed.) D. Maheshwari, Berlin, Heidelberg: Springer, pp. 21-43.

Gao, X., Lu, X., Wu, M., Zhang, H., Pan, R., Tian, J., Li, S. and Liao, H. (2012): Coinoculation with Rhizobia and AMF inhibited soybean red crown rot: From field study to plant defense-related gene expression analysis. PLoS ONE, 7, e33977. doi:10.1371/journal.pone.0033977.

German, M.A., Burdman, S., Okon, Y. and Kigel, J. (2000). Effects of Azospirillum brasilense on root morphology of common bean (Phaseolus vulgaris L.) under different water regimes. Biol Fertil Soils, 32, 259264.

Gholami, A., Shahsavani, S. and Nezarat, S. (2009). The effect of plant growth promoting Rhizobacteria (PGPR) on germination seedling growth and yield of maize. Int J Biol Life Sci, 5, 1.

Gill, S.S., Khan, N.A. and Tuteja, N. (2012). Cadmium at high dose perturbs growth, photosynthesis and nitrogen metabolism while at low dose it up regulates sulfur assimilation and antioxidant machinery in garden cress (Lepidium sativum L.). Plant Sci, 182, 112-120.

Glick, B.R., Penrose, D.M. and Li, J. (1998). A model for the lowering of plant ethylene concentrations by plant growth-promoting bacteria. J Theor Biol, 190, 63-68.

Gopal, M., Gupta, A. and Thomas, G.V. (2013). Bespoke microbiome therapy to manage plant diseases. Front Microbiol, 5, 15.

Grossman, J.M., Schipanski, M.E., Sooksanguan, T. and Drinkwater, L.E. (2011). Diversity of rhizobia nodulating soybean [Glycine $\max$ (Vinton)] varies under organic and conventional management. Appl Soil Ecol, 50, 14-20.

Gupta, G. Panwar, J., Akhtar, M.S. and Jha, P.N. (2012). Endophytic nitrogen-fixing bacteria as biofertilizer. In: Sustainable Agriculture Review, (ed.) E. Lichtfouse. Dordrecht: Springer, pp. 183-221. https://doi.org/10.1007/978-94-007-5449-2.

Gupta, R.P., Kalita, A. and Kapoor, S. (2007). Bioinoculants: A Step towards Sustainable Agriculture. New Delhi: New India Publishing.

Harish, S., Kavino, M., Kumar, N., Balasubramanian, P. and Samiyappan, R. (2009). Induction of defense-related proteins by mixtures of plant growth promoting endophytic bacteria against banana bunchy top virus. Biol Control, 51, 16-25.

Hassen, A.I., Bopape, F.L. and Sanger, L.K. (2016). Microbial inoculants as agents of 
growth promotion and abiotic stress tolerance in plants. In: Microbial Inoculants in Sustainable Agricultural Productivity, (eds.) D. Singh, H. Singh and R. Prabha, New Delhi: Springer, pp. 23-36. https://doi.org/10.1007/978-81-322-2647-5.

Heidari, M. and Golpayegani, A. (2012). Effects of water stress and inoculation with plant growth promoting rhizobacteria (PGPR) on antioxidant status and photosynthetic pigments in basil (Ocimum basilicum L.). $J$ Saudi Soc Agric Sci, 11, 57-61.

Hellriegel and Wilfarth (1886). Unter suchungenurnber die stickst off - Nahrung der Graminum and leguminoseu. Beilagcheft. Z. vers. Rubensur lerine, 1-234 (Cited from Biological fixation of atmospheric nitrogen by Mishustin, E.N. and Shilnikova, London, UK, Macmillan Press Limited).

Hirsch, P.R. and Mauchline, T.H. (2012). Who's who in the plant root microbiome? Nat Biotechnol, 30, 961-962.

Hussain, N., Mujeeb, F., Tahir, M., Khan, G.D., Hassan, N.M. and Bari, A. (2002). Effectiveness of Rhizobium under salinity stress. Asian J Plant Sci, 1, 12-14.

Ilyas, N., Bano, A., Iqbal, S. and Raja, N.I. (2012). Physiological, biochemical and molecular characterization of Azospirillum spp. isolated from maize under water stress. Pak J Bot, 44, 71-80.

Joe, M.M., Jaleel, C.A., Sivakumar, P.K., Zhao, C.X. and Karthikeyan, B. (2009). Coaggregation in Azospirillum brasilensense MTCC-125 with other PGPR strains: Effect of physical and chemical factors and stress endurance ability. J Taiwan Inst Chem Engg, 40, 491-499.

Khalil, S. and Labuschagne, I. (2002). Role of mycorrhizae, pathogens and weeds in sustainable pine forest management Soil biology and biochemistry section, national agricultural research centre, Islamabad, Pakistan. Int J Agric Biol, 4, 1.

Kogel, K.H., Franken, P. and Huckelhovenl, R. (2006). Endophyte or parasite - what decides? Curr Opin Plant Biol, 9, 358-363.

Kohler, J. and Caravaca, F. (2010). An AM fungus and a PGPR intensify the adverse effects of salinity on the stability of rhizosphere soil aggregates of Lactuca sativa Roldan. Soil Biol Biochem, 42, 429434.

Kosuta, S. (2003). Diffusible factor from arbuscular mycorrhizal fungi induces symbiosis-specific expression in roots of Medicago truncatula. Plant Physiol, 131, 952-962.

Lamabam, P.S., Gill, S.S. and Tuteja, N. (2011). Unraveling the role of fungal symbionts in plant abiotic stress tolerance. Plant Signal Behav, 6, 175-191.

Liddycoat, S.M., Greenberg, B.M. and Wolyn, D.J. (2009). The effect of plant growth promoting rhizobacteria on asparagus seedlings and germinating seeds subjected to water stress under greenhouse conditions. Can J Microbiol, 55, 388-394.

Ling, N., Huang, Q., Guo, S. and Shen, Q. (2011). Paenibacillus polymyxa SQR-21 systemically affects root exudates of watermelon to decrease the conidial germination of Fusarium oxysporum f.sp. niveum. Plant Soil, 341, 485-493.

Liu, J.Y., Maldonado-Mendoza, I., Lopez-Meyer, M., Cheung, F., Town, C.D. and Harrison, M.J. (2007). Arbuscular mycorrhizal symbiosis is accompanied by local and systemic alterations in gene expression and an increase in disease resistance in the shoots. Plant J, 50, 529-544.

Mali, G.V. and Bodhankar, M.G. (2009). Antifungal and phytohormone production potential of Azotobacter chroococcum isolates from groundnut (Arachis hypogea L.) rhizosphere. Asian J Exp Sci, 23, 293297.

Malusà, E., Pinzari, F. and Canfora, L. (2016). Efficacy of biofertilizers: Challenges to improve crop production. In: Microbial Inoculants in Sustainable Agricultural Productivity, (eds.) D. Singh, H. Singh and R. Prabha, New Delhi: Springer, pp. 17-40. https://doi.org/10.1007/978-81-322-2644-4.

Malusá, E., Sas-Paszt, L. and Ciesielska, J. (2012). Technologies for beneficial microorganism inocula used as biofertilizers. The Scientific World Journal, 2012, 1-12.

Marulanda, A., Barea, J.M. and Azcon, R. (2009). Stimulation of plant growth and drought 
tolerance by native microorganisms (AM fungi and bacteria) from dry environments: Mechanisms related to bacterial effectiveness. J Plant Growth Regul, 28, 115-124.

Medeiros, F.H.V., Souza, R.M., Medeiros, F.C.L., Zhang, H., Wheeler, T., Payton, P., Ferro, H.M. and Paré, P.W. (2011). Transcriptional profiling in cotton associated with Bacillus subtilis (UFLA285) induced biotic-stress tolerance. Plant Soil, 347, 327-337.

Megali, L., Schlau, B. and Rasmann, S. (2015). Soil microbial inoculation increases corn yield and insect attack. Agronomy for Sustainable Development, 35(4), 15111519. https://doi.org/10.1007/s13593-0150323-0.

Mehdipour-Moghaddam, M.J., Emtiazi, G. and Salehi, Z. (2012). Enhanced auxin production by Azospirillum pure cultures from plant root exudates. J Agr Sci Tech, 14, 985-994.

Mendes, R., Garbeva, P. and Raaijmakers, J.M. (2013). The rhizosphere microbiome: Significance of plant beneficial plant pathogenic and human pathogenic microorganisms. FEMS Microbiol Rev., 37, 634-663.

Menjivar, R.D., Cabrera, J.A., Kranz, J. and Sikora, R.A. (2012). Induction of metabolite organic compounds by mutualistic endophytic fungi to reduce the greenhouse whitefly Trialeurodes vaporariorum (Westwood) infection on tomato. Plant Soil, 352, 233-241.

Mohammadi, K. and Yousef, Y.S. (2012). Bacterial biofertilizers for sustainable crop production: A review. J Agric Biol Sci, 7, 307-316.

Molina-Favero, C., Mónica-Creus, C., LucianaLanteri, M., Correa-Aragunde, N., Lombardo, M.C., Barassi, A.C. and Lamattina, L. (2007). Nitric oxide and plant growth promoting Rhizobacteria: Common features influencing root growth and development. Adv Bot Res, 46, 1-33.

Mujawar, M.I. (2014). Bacteria and fungi can contribute to nutrients. Journal of King Saud University, 26(1), 1-20.

Murphy, J.F., Reddy, M.S., Ryu, C.M., Kloepper,
J.W. and Li, R. (2003). Rhizobacteria mediated growth promotion of tomato leads to protection against cucumber mosaic virus. Phytopathology, 93, 1301-1307.

Murphy, J.F., Zehnder, G.W., Schuster, D.J., Sikora, E.J., Polstan, J.E. and Kloepper, J.W. (2000). Plant growth promoting rhizobacteria mediated protection in tomato against tomato mottle virus. Plant Dis, 84, 79-84.

Neeraj, K.S. (2011). Organic amendments to soil inoculated arbuscular mycorrhizal fungi and Pseudomonas fluorescens treatments reduce the development of root-rot disease and enhance the yield of Phaseolus vulgaris L. Eur J Soil Biol, 47, 288-295.

Nehra, K., Yadav, S.A., Sehrawat, A.R. and Vashishat, R.K. (2007). Characterization of heat resistant mutant strains of Rhizobium $s p$. [Cajanus] for growth, survival and symbiotic properties. Indian J Microbiol, 47, 329-335.

Nina, K., Thomas, W.K. and Prem, S.B. (2014). Beneficial organisms for nutrient uptake. VFRC report 2014/1, virtual fertilizer research center. Washington, DC: Wageningen Academic Publishers, 63.

Ogbo, F.C. (2010). Conversion of cassava wastes for biofertilizer production using phosphate solubilizing fungi. Bioresour Technol, 101, 4120-4124.

Pandey, P.K., Yadav, S.K., Singh, A., Sarma, B.K., Mishra, A. and Singh, H.B. (2012). Cross-species alleviation of biotic and abiotic stresses by the endophyte Pseudomonas aeruginosa PW09. J Phytopathol, 160, 532-539.

Pandey, S., Shrivastava, A.K., Rai, R. and Rai, L.C. (2013). Molecular characterization of Alr1105 a novel arsenate reductase of the diazotrophic cyanobacterium Anabaena sp. PCC7120 and decoding its role in abiotic stress management in Escherichia coli. Plant Mol Biol, 83, 417-432.

Park, J., Bolan, N., Megharaj, M. and Naidu, R. (2010). Isolation of phosphate-solubilizing bacteria and characterization of their effects on lead immobilization. Pedologist, 53, 6775.

Patil, P.L. and Medhane, N.S. (1974). Seed inoculation studies in gram (Cicer 
arietinum) with different strains of Rhizobium sp. Plant Soil, 40, 221-223.

Paul, D. and Nair, S. (2008). Stress adaptations in a plant growth promoting Rhizobacterium (PGPR) with increasing salinity in the coastal agricultural soils. J Basic Microbiol, $48,1-7$.

Peng, G., Yuan, Q., Li, H., Zhang, W. and Tan, Z. (2008). Rhizobium oryzae sp. nov., isolated from the wild rice Oryza alta. Int J Syst Evol Microbiol, 58, 2158-2163.

Perrig, D., Boiero, M.L., Masciarelli, O.A., Penna, C., Ruiz, O.A., Cassan, F.D. and Luna, M.V. (2007). Plant-growth promoting compounds produced by two agronomically important strains of Azospirillum brasilense, and implications for inoculant formulation. Appl Microbiol Biotechnol, 75, 1143-1150.

Pindi, P.K. and Satyanarayana, S.D.V. (2012). Liquid microbial consortium- a potential tool for sustainable soil health. J Biofertil Biopest, 3, 4.

Plett, J.M., Kemppainen, M., Kale, S.D., Kohler, A., Legue, V., Brun, A., Tyler, B.M., Pardo, A.G. and Martin, F. (2011). A secreted effector protein of Laccaria bicolor is required for symbiosis development. Curr Biol, 21, 1197-1203.

Ramachandran, V.K., East, A.K., Karunakaran, R., Downie, J.A. and Poole, S.P. (2011). Adaptation of Rhizobium leguminosarum to pea, alfalfa and sugar beet rhizosphere investigated by comparative transcriptomics. Genome Biol, 12, 106-109.

Rashid, M.H., Schafer, H., Gonzalez, J. and Wink, M. (2012). Genetic diversity of rhizobia nodulating lentil (Lens culinaris) in Bangladesh. Syst Appl Microbiol, 35, 98109.

Rashid, M.I., Mujawar, L.H., Shahzad, T., Almeelbi, T., Ismail, I.M. and Oves, M. (2016). Bacteria and fungi can contribute to nutrients bioavailability and aggregate formation in degraded soils. Microbiological Research, 183, 26-41. https://doi.org/10.1016/j.micres.2015.11.00 7.

Ratti, N., Kumar, S., Verma, H.N. and Gautams, S.P. (2001). Improvement in bioavailability of tricalcium phosphate to Cymbopogon martini var. motia by rhizobacteria, AMF and azospirillum inoculation. Microbiology Research, 156, 145-149.

Revillas, J.J., Rodelas, B., Pozo, C., MartinezToledo, M.V. and Gonzalez, L.J. (2000). Production of B-Group vitamins by two Azotobacter strains with phenolic compounds as sole carbon source under diazotrophicand adiazotrophic conditions. $J$ Appl Microbiol, 89, 486-493.

Riedlinger, J., Schrey, S.D., Tarkka, M.T., Hampp, R., Kapur, M. and Fiedler, H.P. (2006). Auxofuran, a novel substance stimulating growth of fly agaric, produced by the mycorrhiza helper bacterium Streptomyces AcH 505. Appl Environ Microbiol, 72, 3550-3557.

Roberts, N.J., Morieri, G., Kalsi, G., Rose, A., Stiller, J., Edwards, A., Xie, F., Gresshoff, P.M., Oldroyd, G.E., Downie, J.A. and Etzler, M.E. (2013). Rhizobial and mycorrhizal symbioses in Lotus japonicus require lectin nucleotide phosphohydrolase, which acts upstream of calcium signaling. Plant Physiol, 161, 556-567.

Roy, M. and Srivastava, R.C. (2013). Assembling BNF system in rice plant: Frontier areas of research. Curr Sci, 104, 3-10.

Ruiz-Sanchez, M., Aroca, R., Munoz, Y., Polon, R. and Ruiz-Lozano, J.M. (2010). The arbuscular mycorrhizal symbiosis enhances the photosynthetic efficiency and the antioxidative response of rice plants subjected to drought stress. J Plant Physiol, 167, 862-869.

Ryu, C.M., Farag, M.A., Hu, C.H., Reddy, M.S., Kloepper, J.W. and Pare, P.W. (2004). Bacterial volatiles induce systemic resistance in Arabidopsis. Plant Physiol, 134, 1017-1026.

Sahoo, R.K., Ansari, M.W., Dangar, T.K., Mohanty, S. and Tuteja, N. (2013a). Phenotypic and molecular characterization of efficient nitrogen fixing Azotobacter strains of the rice fields. Protoplasma, doi:10.1007/s00709-013-0547-2.

Sahoo, R.K., Ansari, M.W., Pradhan, M., Dangar, T.K., Mohanty, S. and Tuteja, N. (2014). Phenotypic and molecular characterization of efficient native Azospirillum strains from rice fields for crop improvement. 
Protoplasma, doi:10.1007/s00709-0130607-7.

Sahoo, R.K., Bhardwaj, D. and Tuteja, N. (2013b). Biofertilizers: A sustainable ecofriendly agricultural approach to crop improvement. In: Plant Acclimation to Environmental Stress. (Eds.) Tuteja, N., Gill, S.S. LLC 233 Spring Street, New York, 10013, USA: Springer Science plus Business Media, 403-432.

Saikia, S.P., Bora, D., Goswami, A., Mudoi, K.D. and Gogoi, A. (2013). A review on the role of Azospirillum in the yield improvement of non-leguminous crops. Afr J Microbiol Res, 6, 1085-1102.

Salvioli, A., Zouari, I., Chalot, M. and Bonfante, P. (2012). The arbuscular mycorrhizal status has an impact on the transcriptome profile and amino acid composition of tomato fruit. BMC Plant Biol, 12, 44.

Samuel, S. and Muthukkaruppan, S.M. (2011). Characterization of plant growth promoting rhizobacteria and fungi associated with rice, mangrove and effluent contaminated soil. Curr Bot, 2, 22-25.

Sarig, S., Blum, A. and Okon, Y. (1992). Improvement of the water status and yield of field-grown grain sorghum (Sorghum bicolor) by inoculation with Azospirillum brasilense. J Agric Sci, 110, 271-277.

Sashidhar, B. and Podile, A.R. (2010). Mineral phosphate solubilisation by rhizosphere bacteria and scope for manipulation of the direct oxidation pathway involving glucose dehydrogenase. J Appl Microbiol, 109, 112.

Schnider-Keel, U., Seematter, A., Maurhofer, M., Blumer, C., Duffy, B., Gigot-Bonnefoy, C., Reimmann, C., Notz, R., Defago, G., Haas, D. and Keel, C. (2000). Autoinduction of 2,4-diacetylphloroglucinol biosynthesis in the biocontrol agent Pseudomonas fluorescens $\mathrm{CHA} 0$ and repression by the bacterial metabolites salicylate and pyoluteorin. J Bacteriol, 182, 1215-1225.

Sevilla, M., Burris, R.H., Gunapala, N. and Kennedy, C. (2001). Comparison of benefit to sugarcane plant growth and $15 \mathrm{n} 2$ incorporation following inoculation of sterile plants with Acetobacter diazotrophicus wild-type and Nif-mutant strains. Mol Plant-Microbe Interact, 14, 358-366.

Sharma, P., Sardana, V. and Kandola, S.S. (2011). Response of groundnut (Arachis hypogaea L.) to Rhizobium inoculation. Libyan Agric Res Centre J Int, 2, 101-104.

Shridhar, B.S. (2012). Review: Nitrogen fixing microorganisms. International Journal of Microbiological Research, 3(1), 46-52.

Sieberer, B.J., Chabaud, M., Timmers, A.C., Monin, A., Fournier, J. and Barker, D.G. (2009). A nuclear-targeted cameleon demonstrates intranuclear $\mathrm{Ca}^{2+}$ spiking in Medicago truncatula root hairs in response to rhizobial nodulation factors. Plant Physiol, 151, 1197-1206.

Singh, J.S., Pandey, V.C. and Singh, D.P. (2011). Efficient soil microorganisms: A new dimension for sustainable agriculture and environmental development. Agric Ecosyst Environ, 140, 339-353.

Smith, S., Lakobsen, I., Gronlund, M. and Smith, F.A. (2011). Roles of arbuscular mycorrhizas in plant phosphorus nutrition: Interactions between pathways of phosphorus uptake in arbuscular mycorrhizal roots have important implications for understanding and manipulating plant phosphorus acquisition. Plant Physiol, 156, 1050-1057.

Splivallo, R., Fischer, U., Gobel, C., Feussner, I. and Karlovsky, P. (2009). Truffles regulate plant root morphogenesis via the production of auxin and ethylene. Plant Physiol, 150, 2018-2029.

Sudha, M., Gowri, R.S., Prabhavati, P., Astapriya, P., Devi, S.Y. and Saranya, A. (2012). Production and optimization of indoleacetic-acid by indigenous micro flora using agro waste as substrate. Pakistan $J$ Biological Sci, 15, 39-43.

Suyal, D.C., Soni, R., Sai, S. and Goel, R. (2016). Microbial inoculants as biofertilizers. In: Microbial Inoculants in Sustainable Agricultural Productivity, (eds.) D. Singh, H. Singh and R. Prabha, New Delhi: Springer. https://doi.org/10.1007/978-81322-2647-5.

Tang, J., Wang, R., Niu, X., Wang, M. and Zhou, Q. (2010). Characterization on the rhizoremediation of petroleum 
contaminated soil as affected by different influencing factors. Biogeosciences Discuss, 7, 4665-4688.

Thamer, S. Schädler, M., Bonte, D. and Ballhorn, D.J. (2011). Dual benefit from a below ground symbiosis: nitrogen-fixing rhizobia promote growth and defense against a specialist herbivore in cyanogenic plant. Plant Soil, 341(1-2), 1209-1219. https://doi.org/10.1007/s11104-010-0635-4.

Toussaint, J.P., Kraml, M., Nell, M., Smith, S.E., Smith, F.A., Steinkellner, S., Schmiderer, H. and Novak, V. (2008). Effect of Glomus mosseae on concentrations of rosmarinic and caffeic acids and essential oil compounds in basil inoculated with Fusarium oxysporum $f$. sp. basilica. Plant Pathol, 57, 1109-1116.

Tripura, C.B., Reddy, P.S., Reddy, M.K., Sashidhar, B. and Podile, A.R. (2007). Glucose dehydrogenase of a rhizobacterial strain of Enterobacter asburiae involved in mineral phosphate solubilization shares properties and sequence homology with other members of enterobacteriaceae. Indian J Microbiol, 47, 126-131.

Tromas, A., Parizot, B., Diagne, N., Champion, A. and Hocher, V. (2012). Heart of endosymbioses: transcriptomics reveals a conserved genetic program among arbuscular mycorrhizal, actinorhizal and legume-rhizobial symbioses. PLOS ONE, 7, e44742.

Vessey, J.K. (2003). Plant growth promoting rhizobacteria as biofertilizers. Plant and
Soil, $\quad$ 255(2), 571-586. https://doi.org/10.1023/A:1026037216893.

Wani, S.A., Chand, S. and Ali, T. (2013). Potential use of Azotobacter chroococcum in crop production: An overview. Curr Agric Res J, 1, 35-38.

Weller, D.M., Mavrodi, D.V., van Pelt, J.A., Pieterse, C.M., van Loon, L.C. and Bakker, P.A. (2012). Induced systemic resistance in Arabidopsis thaliana against Pseudomonas syringae pv. tomato by 2,4diacetylphloroglucinol-producing

Pseudomonas fluorescens. Phytopathology, 102, 403-412.

Yang, J.W., Kloepper, J.W. and Ryu, C.M. (2009). Rhizosphere bacteria help plants tolerate abiotic stress. Trends Plant Sci, 14, $1-4$.

Yao, L., Wu, Z., Zheng, Y., Kaleem, I. and Li, C. (2010). Growth promotion and protection against salt stress by Pseudomonas putida Rs-198 on cotton. European J Soil Biol, 46, 49-54.

Zhang, N., Kai, W., He, X., Li, S., Zhang, Z., Shen, B., Yang, X., Zhang, R., Huang, Q. and Shen, Q. (2011). A new bioorganic fertilizer can effectively control banana wilt by strong colonization with Bacillus subtilis N11. Plant Soil, 344, 87-97.

Zhang, Q., Blaylock, L.A. and Harrison, M.J. (2010). Two Medicago truncatula HalfABC transporters are essential for arbuscule development in arbuscular mycorrhizal symbiosis. Plant Cell, 22, 1483-1497.

\section{How to cite this article:}

Sanjay Swami. 2020. Soil Microbes for Securing the Future of Sustainable Farming. Int.J.Curr.Microbiol.App.Sci. 9(04): 2687-2706. doi: https://doi.org/10.20546/ijcmas.2020.904.320 